\title{
Meeting Energy Demands Through Mining
}

\section{Amosu C. 0.}

Abstract: The Mineral and Mining industry is a huge energy requiring sector which demands connections to a viable electric power origin and reference. With the upsurge of these mineral requests and decreasing valued grades of ores, energy aspiration is approximated to sky-rocket to $36 \%$ by the year 2035 . It is even projected to accelerate geometrically from the fact that sophistication and powering of the mine locations speeds up the stability into the necessity of energy applications and its requirements derived from fossil fuels utilized to generate electricity. This paper discusses other fossilized fuel-based materials for generation of electricity.

Keywords: Energy, Mining, Coal, Natural Gas, Crude Oil, Rare-Earth Metals, Platinum, Molybdenum, Nickel. Cobalt, Lithium, Bitumen, Limestone, Oil Shale, Thorium, Uranium

\section{INTRODUCTION}

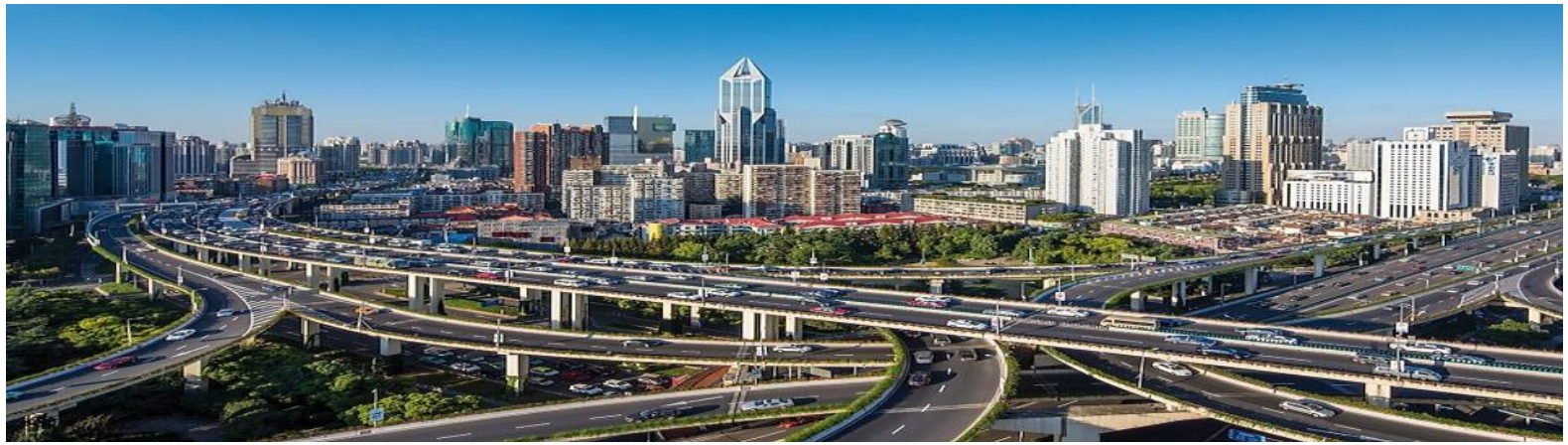

Figure 1: The big picture of meeting energy demands

\section{Coal Resource:}

Coal is a sedimentary-based rock that is either black or brownish-black consisting of carbon and the hydrocarbons. Coal is combustible and a non-renewable energy source. Its energy comes from the energy stored in plants.
Coal is transported by train, barge, ship, conveyor, truck, and pipeline. (Energy Kid's page, 2007). Coal is grouped into four major types which composes of anthracite having about 95\% carbon; lignite having about $34 \%$ carbon; higher-bituminous having about 44\% carbon and lowerbituminous having about $85 \%$ carbon).

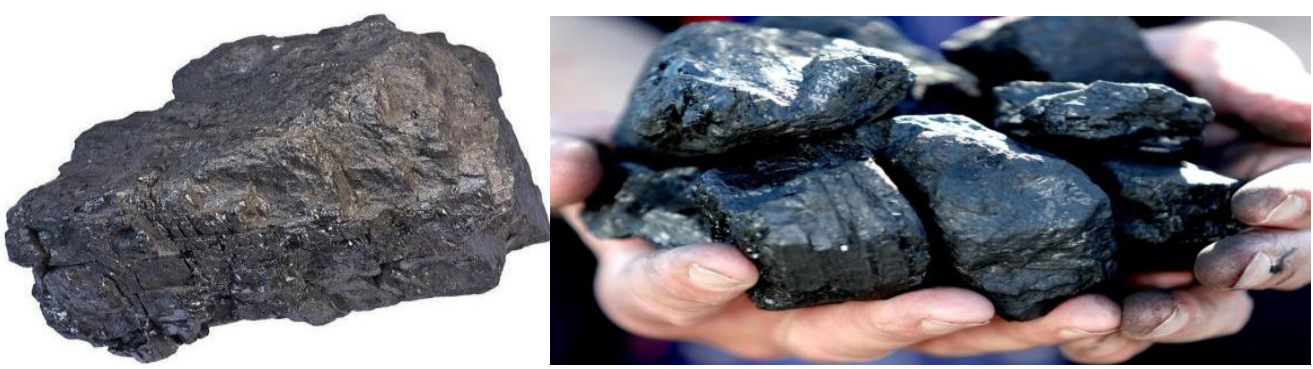

Figure 2: Coal (indiamart.com and theguardian.com)

The proven coal reserves worldwide 1 is over 860 billion tonnes which will not get exhausted for the next 118 years at current rates of consumption. Coal reserves are recoverable in about 70 countries with China, India, USA, and Russia having the largest. This provides economic opportunity for such countries.

Manuscript received on 09 October 2021 | Revised Manuscript received on 25 October 2021 | Manuscript Accepted on 15 November 2021 | Manuscript published on 30 November 2021. * Correspondence Author

Amosu C. O.*, Lecturer and Researcher, Department of Mineral and Petroleum Engineering, Yaba College of Technology, Lagos, Nigeria. Email: cyril.amosu@yabatech.edu.ng

(c) The Authors. Published by Lattice Science Publication (LSP). This is an open access article under the CC-BY-NC-ND license (http://creativecommons.org/licenses/by-nc-nd/4.0/)

A lot of these nations with huge deposits of coal possesses significant processing of coal, even though many nations with quantifiable deposit lags being exploited within mega scale abounds (Coal-Energy for Sustainable Development, 2012).Energy stored in coal when burned is used for the production of electricity power generation used transmitted into the power line grid, and utilized for domestic, administrative and industrial heating, cooling, communication, lighting, transportation, agriculture, etc. .

\section{Natural Gas Resource:}

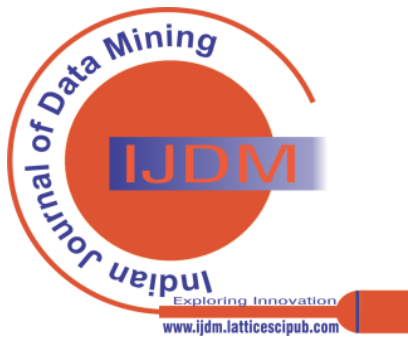




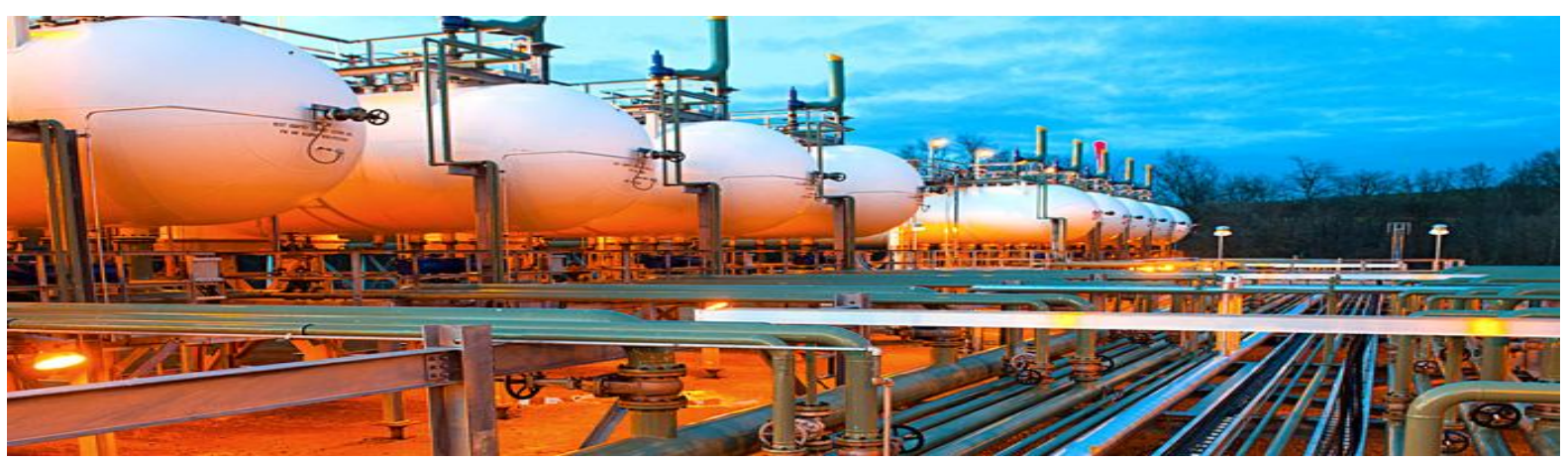

Figure 3: Natural Gasas Ultimate Solution (businessday.ng)

Natural gas isnaturally clean, colourless, tasteless and odourless methane gas, with a trace of ethane. It is utilized forelectricity generation domestically and industrially, especially for transportation, fuels, detergents, cosmetics, plastics (Maarten, 2015).Natural gas is grouped into two maintypes (Conventional Gas - low specific gravity; Unconventional Gas - low permeability).

\section{Crude Oil Resource:}
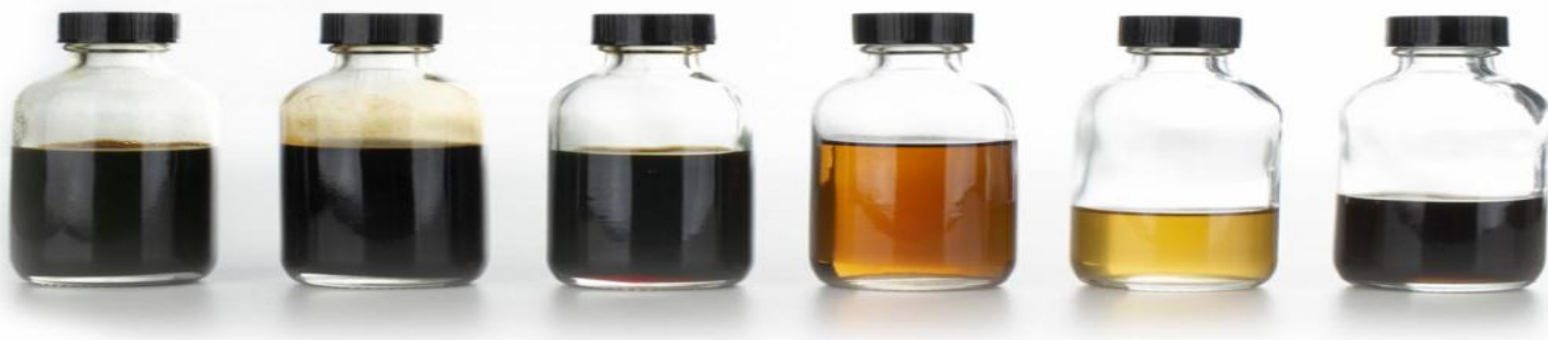

Figure 4: Sample of crude oil with different colours

\section{Rare-Earth Metals Resource:}

Rare-earth is a group of 17 chemical elements with distinctcharacteristics in the periodic table which includes Cerium, Yttrium, Lanthanum and Neodymium. Rare-earth are scarcely found in concentrations that are extractable. The demand for rare earth elements has sky-rocketed, but their minable deposits is limited, commercially (Hobart, 2020).
Crude oil is a naturally occurring fossil liquid fuel found in the sub-surface made of hydrocarbon. It is applied in a) transportation, b) heating, c) electricity generation, c) plastics, and d) petroleum products. The petroleum market is projected to attain estimates close to about two thousand billion USD, by early twenty-first century. Crude oil trading provides perfect privileges to gain in almost the entire market situation in the face of thepolitical and economic systems of the world.

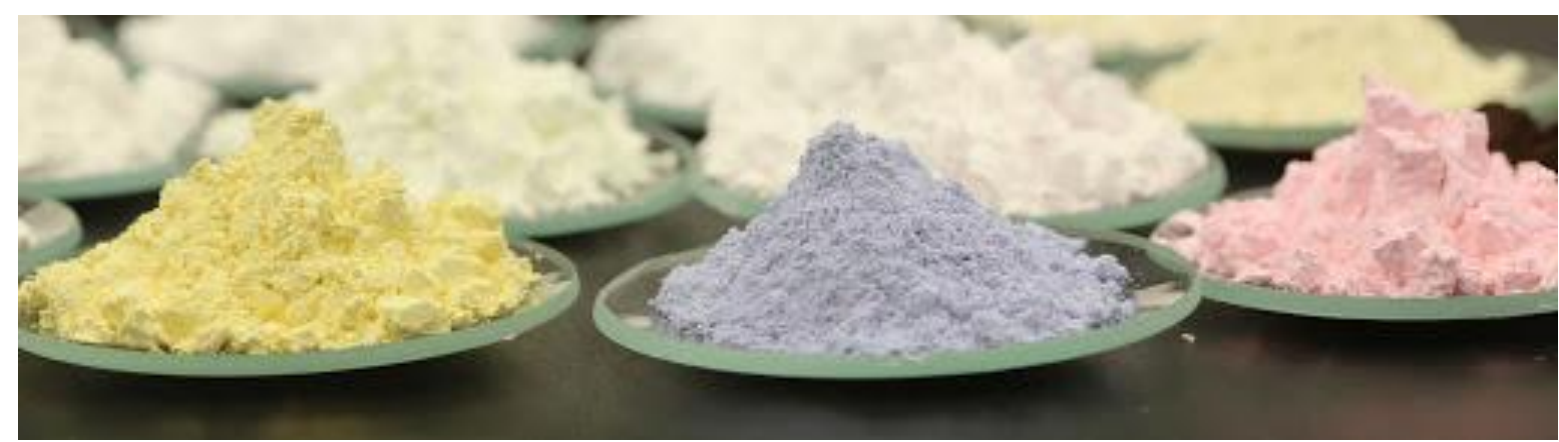

Figure 5: Rare-Earth Oxides (jiatom.com)

\section{Platinum Resource:}

A platinum electrode is used as the. Platinum is a metal that has high resale value and is best for material with great sentimental as a wedding ring. It is resistant to wear and tear. It is more expensive than gold. Its price varies side-by-

They are applied in: a) chemical catalyst, b) Glass polishing, c) metallurgy and alloy. The global market size for these earth entities were estimated at about three billion USD in the late twentieth century. Rare-earth are used in: a) computer memory, b) DVDs,c) rechargeable batteries, d) cell phones, e) fluorescent lighting, f) magnet, etc. (Grand View Research, 2019).

side to the market forces of demand and supply, during the times of economic sustenance, equilibrium and re-sizing.

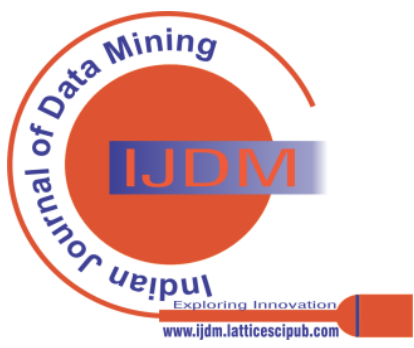


Platinum is applied in: a) Catalytic converters, b) laboratory equipment, c) Electrical contacts and electrodes, d) Platinum thermometers, e) dentistry equipment f) automobiles, g) trucks and f) jewellery.
Its use are for: a) Computer hard disks, b) thermocouples, c) Optical fibres, d) LCDs, e) Turbine blades, f) Spark plugs, g) dental filling, h) cathode and reference electrode and i) chemotherapy drugs used to treat cancer, etc.
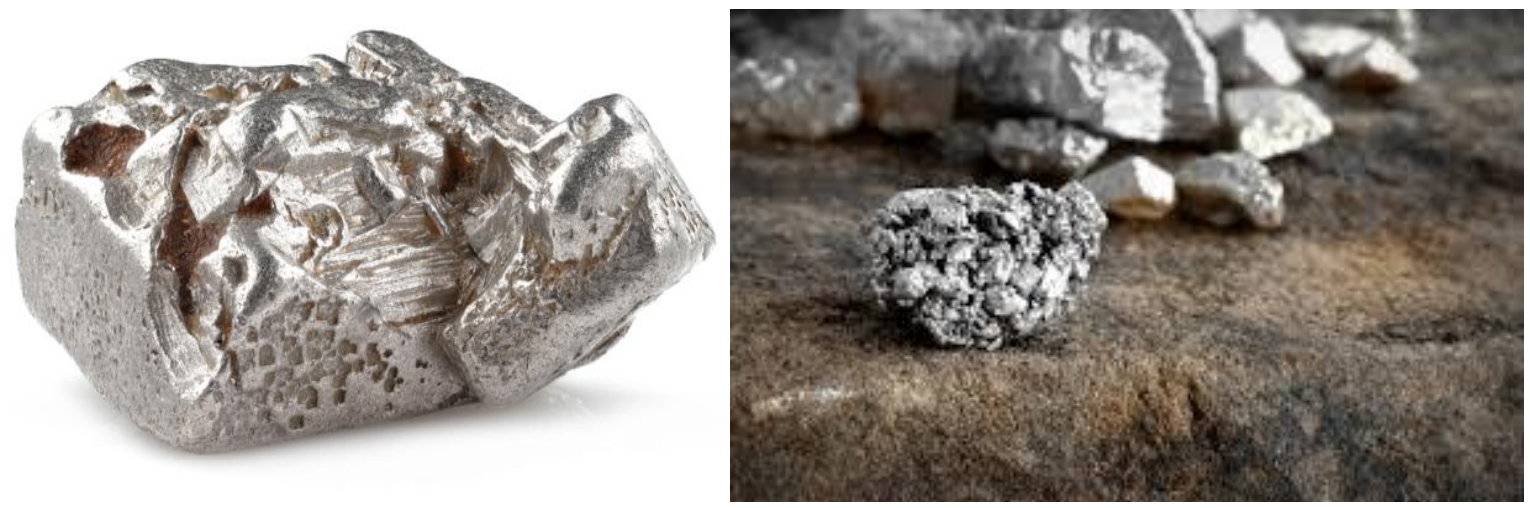

Figure 6: Platinum stones (Mining-technology.com)

\section{Molybdenum Resource:}

Molybdenum is a grey powdery and ductile metal that is silvery-white and highly corrosion-resistant. It is applied in : a) missiles, b) engine parts, c) drills, d) saw blades, e) electric heater filaments, f) lubricant additives, g) ink for circuit boards, h) protective coatings in boilers and i) as a catalyst in the petroleum industry (Traci, 2019). The global market for molybdenum is driven by the increases demand from industries that are of mega-scale in which high price is a major constraint of this market. Its resources is depleting, but manufacturers are searching ways to get new energy sources, that is needed for the establishing the renewable energy production plants, which in turn, is driving the molybdenum market for the development and construction of production facilities, especially in the steel and chemicals industries. It is applied to: a) oil and gas, b) automotive, c) aerospace, d) defence, e) electronics, f) medical, and g) the construction industry. The global molybdenum price-ground is divided: to Africa, Asia, Pacific, Europe, South America, North America, Middle East (Transparency Market Research, 2018)

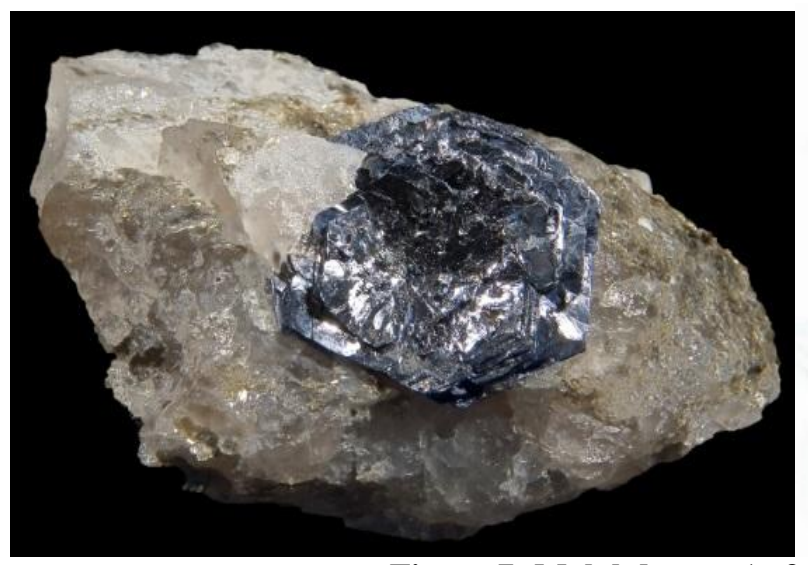

Figure 7: Molybdenum (refractorymetal.org and reade.com)

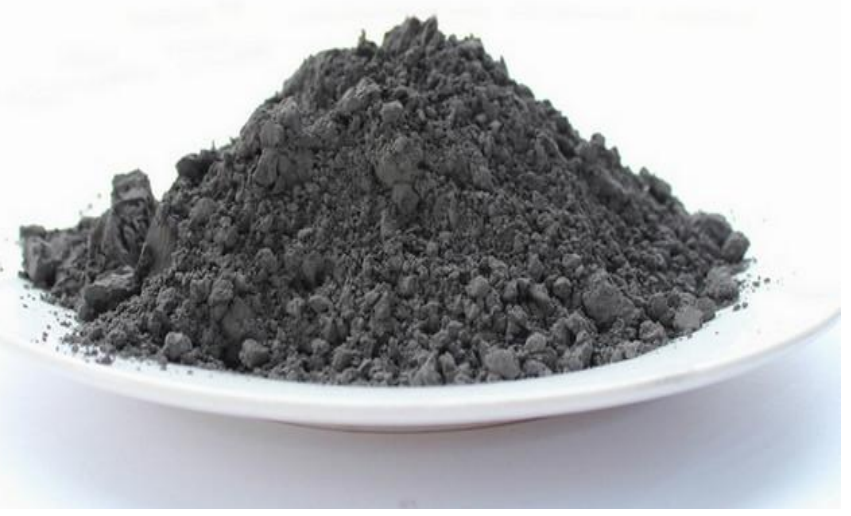

batteries that are nickel-based measuring up with the demand of our ever increasing number of people to sustain needs of power is also sustaining the size of the market. Similar need is encountered in the stainless steel products internationally. non-ferrous alloys and super alloys, c) metallurgy - stainless steel and alloy steel, d) battery electrodes and fuel Cells, e) powder metallurgy part, f) electroplating, and g) Casting. Its end-users are the following industries: a) industrial machinery, b) construction, c) electrical and electronics, d) chemical, e) petrochemical, f) fabricated metal products, g) consumer durables, and h) transportation and defence. (Sharma, 2020).It is widely available in: a) Europe, b) Africa, c) North America, d) Asia Pacific, d) South America, e) Middle East (Dipali, 2021).The production of

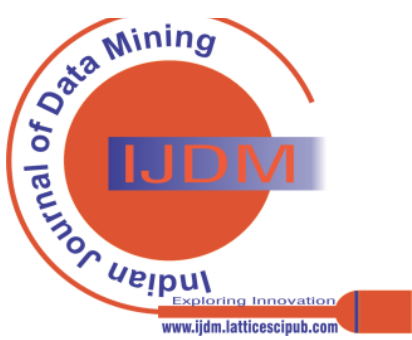



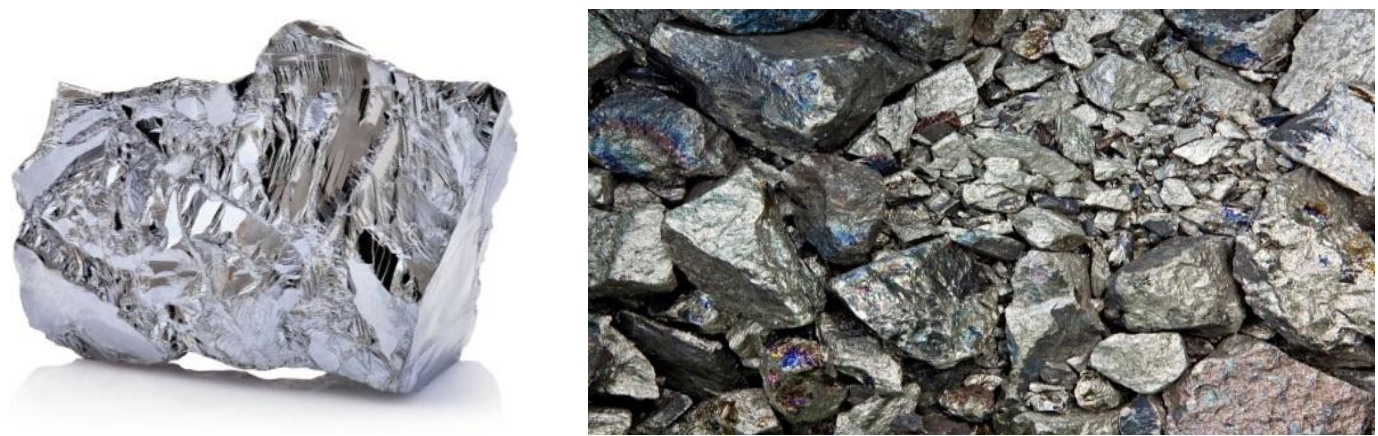

Figure 8: Nickel Production (Mining-technology.com)

\section{Cobalt Resource:}

The increasing applications in end-user industries propel the demand for cobalt carbonate. Its shelf life and enhanced mixing properties pointers as themain factor for its increased embrace across theses industries. It is applied in: a) paint additives, b) paint pigments, c) coating additives, and d) agricultural chemicals. Its end-users are: a) paint Industry, b) agriculture industry, c) automotive industry, d) aerospace industry, e) pharmaceutical industry, f) chemical industry, and g) food Industry(Dipali, 2021).

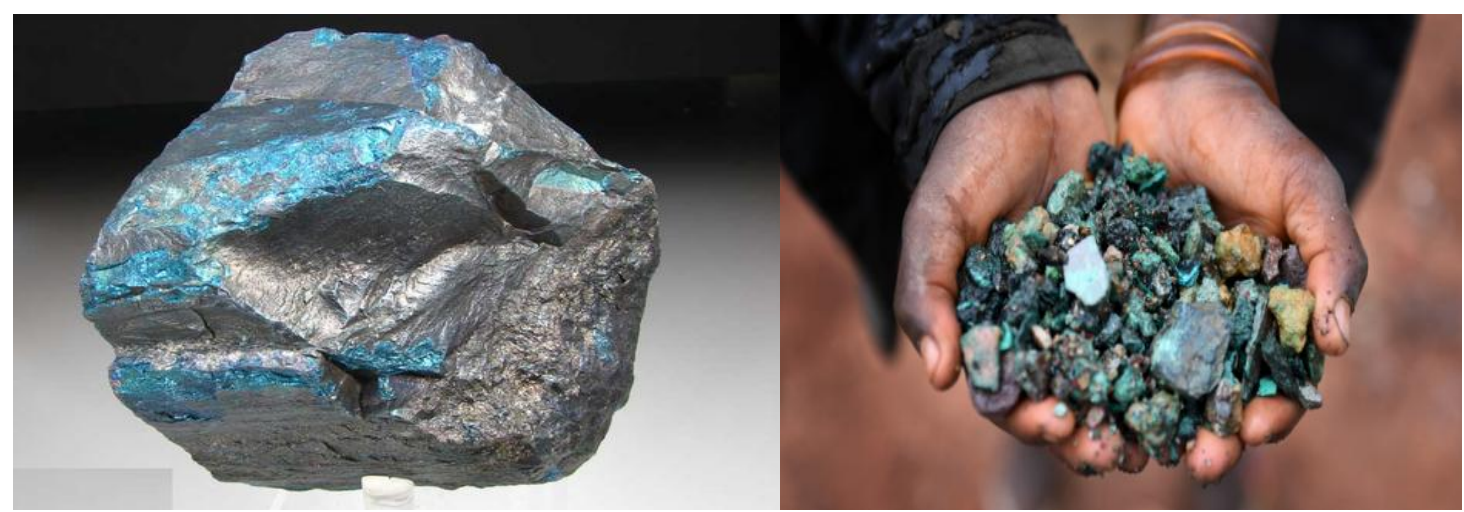

Figure 9: High grade Cobalt Ore(indiamart.com and industriall-union org)

9. Lithium Resource:

Its major application is in the lithium ion batteries (LIBs)which is a high energy storage efficient and density batteries, with long lifespanand friendliness environmentally (Scrosati, Hassoun and Sun, 2011).
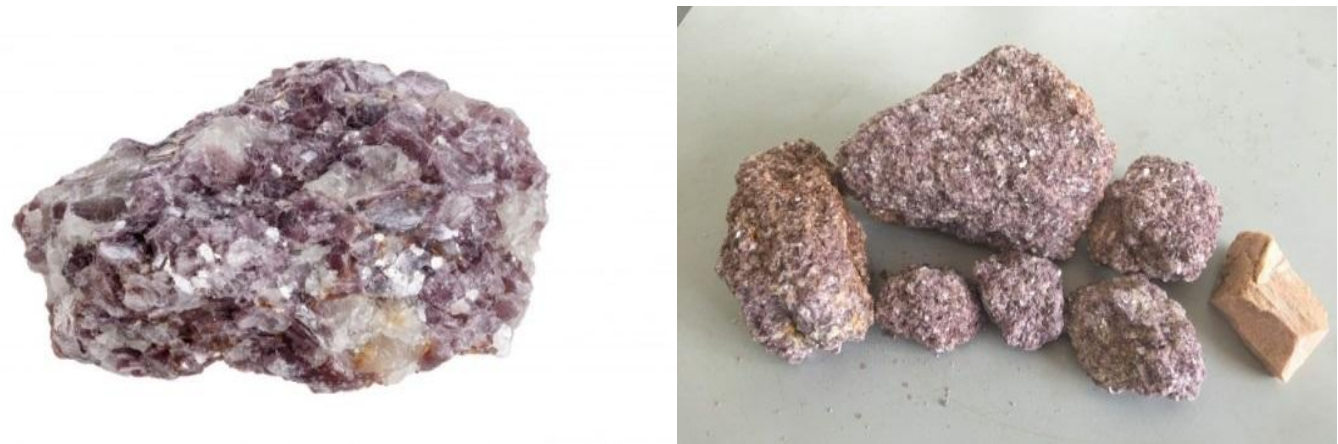

Figure 10: Lithium Ores (mineralseducationcoalition.org and startuptipsdaily.com)

\section{BitumenResource:}

Natural Bitumen is a pasty-like derivative of crude oil fossil energy resource. It is a main origin of heavy petroleumhaving promising prospects as a potential source of energy. Its properties make it a cleaner and better source of energy generation. (Adedimila, 2000). Nigeriahas the second largest deposit of bitumen globally after AlbertaCanada(Owolabi, 1997).

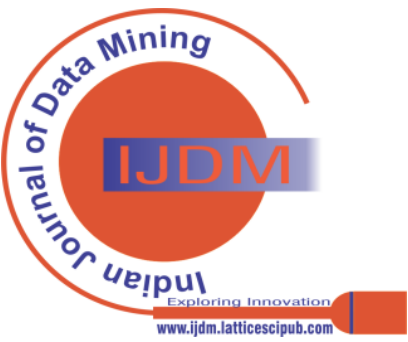




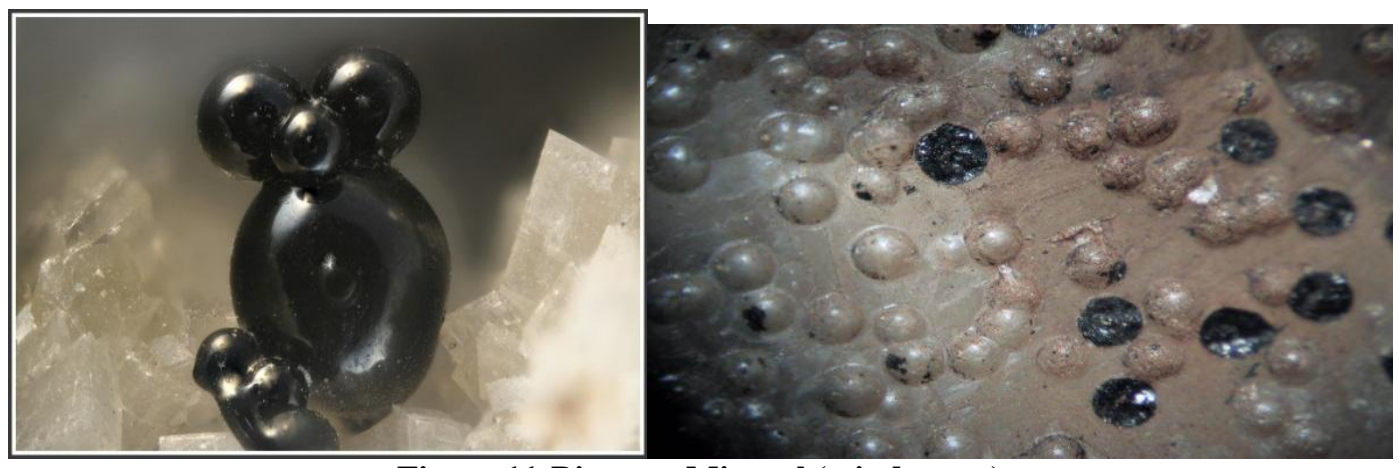

Figure 11:Bitumen Mineral (mindat.org)

\section{LimestoneResource:}

Limestone is a rock that sedimentary-basedwhich consists majorly of calcium carbonate $\left(\mathrm{CaCO}_{3}\right)$ - found inaragonite or calcite, and traces of magnesium carbonate $\mathrm{CaMg}\left(\mathrm{CO}_{3}\right)_{2}$ - dolomite.Limestone flour applied in: used in a) power and heat generation, b) glass-making, c) papermaking, d) construction industry, e) agricultural industry, f) coal mining, g) plastics and rubber production(Lewicka, Szlug, Burkowicz and Galos, 2020).
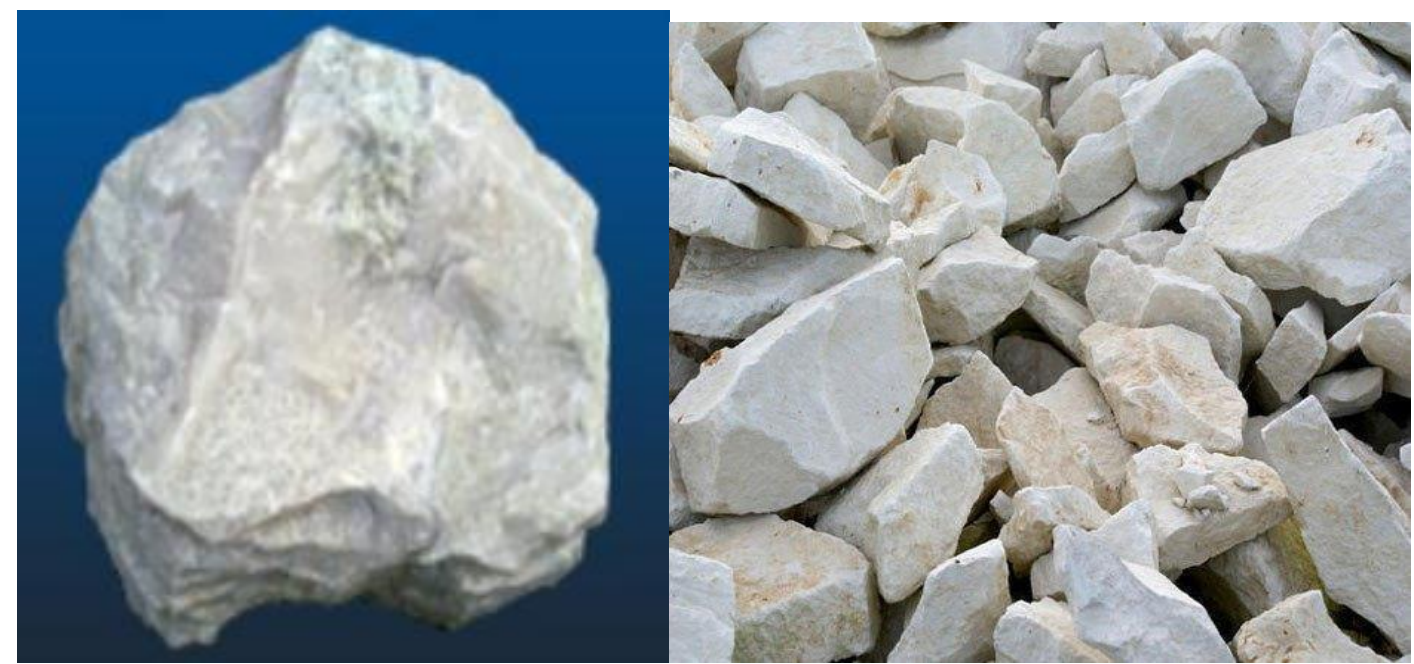

Figure 12:Limestone rocks (indiamart.com).

\section{Oil shaleResource:}

Oil shale is a rock that is hydrocarbon-bearing (has about $25 \%$ of organic matter made up of Carbon, Hydrogen, Oxygen and traces of Nitrogen and Sulphur), which occurs in about 100 deposits in 27 nations, globally. Oil shale resources is one of the vastest and abundantly reserved fossil energy in the worldwide located in China, Germany, Australia, USA ,Brazil, Estonia, Russia, Jordan, Thailand, etc. Itsspent shale is applied in: a) cement industry, b) road constructions, and c) building materials (Basieso M.A. et al., 2008).

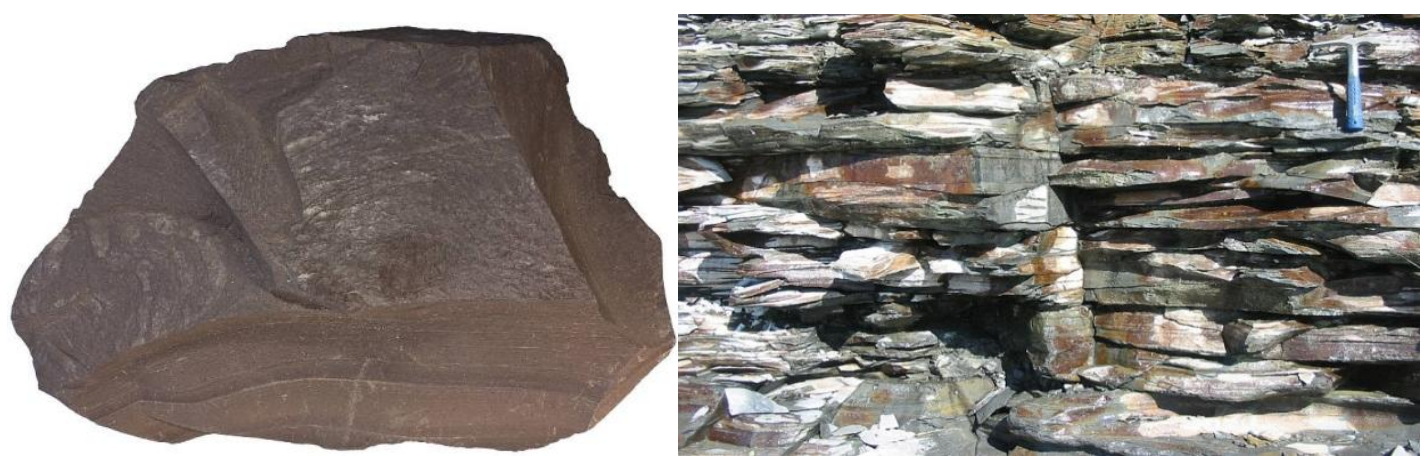

Figure 13:Oil Shale Sedimentary Rock (sandatlast.com)

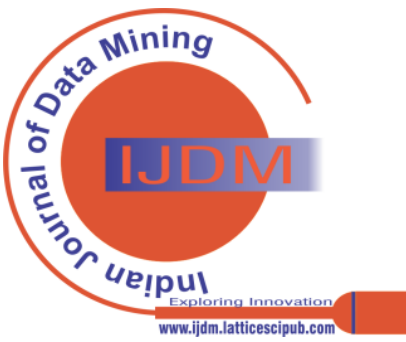




\section{ThoriumResource:}

Thorium is an energy-dense fossil fuels found from crust of theearth (Sinding-Larson and Friedrich, 2012) used as a current day source of energy more than enough to stand for countless years. (Kutsch and Kennedy, 2013). It is the perfect fuel for a various kinds of reactor -Molten Salt Reactor (MSR) (Peggs et al., 2012).One pound of Thorium can produce as much energy as eight hundred and fifty tons of coal (Coal Energy, 2013).

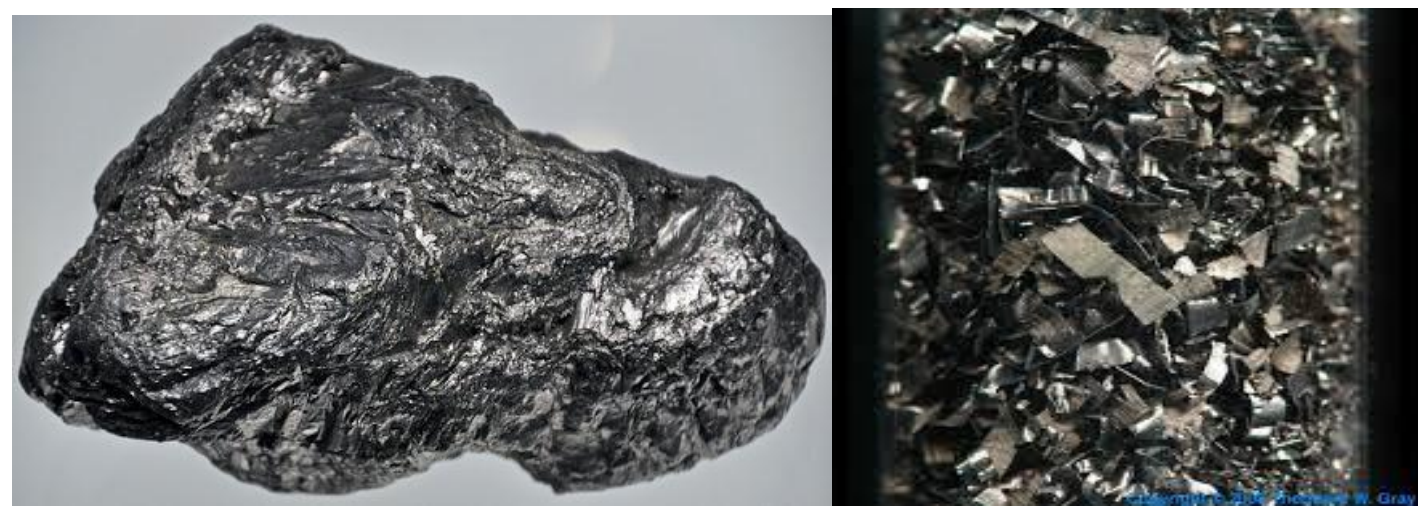

Figure 13:Thorium Mineral Concentrates (tinklink.com and theoregray.com)

\section{Uranium Resource:}

Uranium is a natural isotopic nuclear energy-based fossil fuel which is estimated as 99.3\% natural, i.e. U-238 (Sinding-Larson and Friedrich, 2012) and about $0.7 \%$ of natural, i.e. U-235. It is applied in: a) fuel used for nuclear power reactors (Kutsch and Kennedy, 2013); b) use in medicine; c) enhanced enveloping of electronical produced glass metals, d) additive in coloured glass (Degueldre and Joyce,2020); e) radio discoveries, f) radioactive army power sector (Wang, Mai, Guan and Liu, 2020).

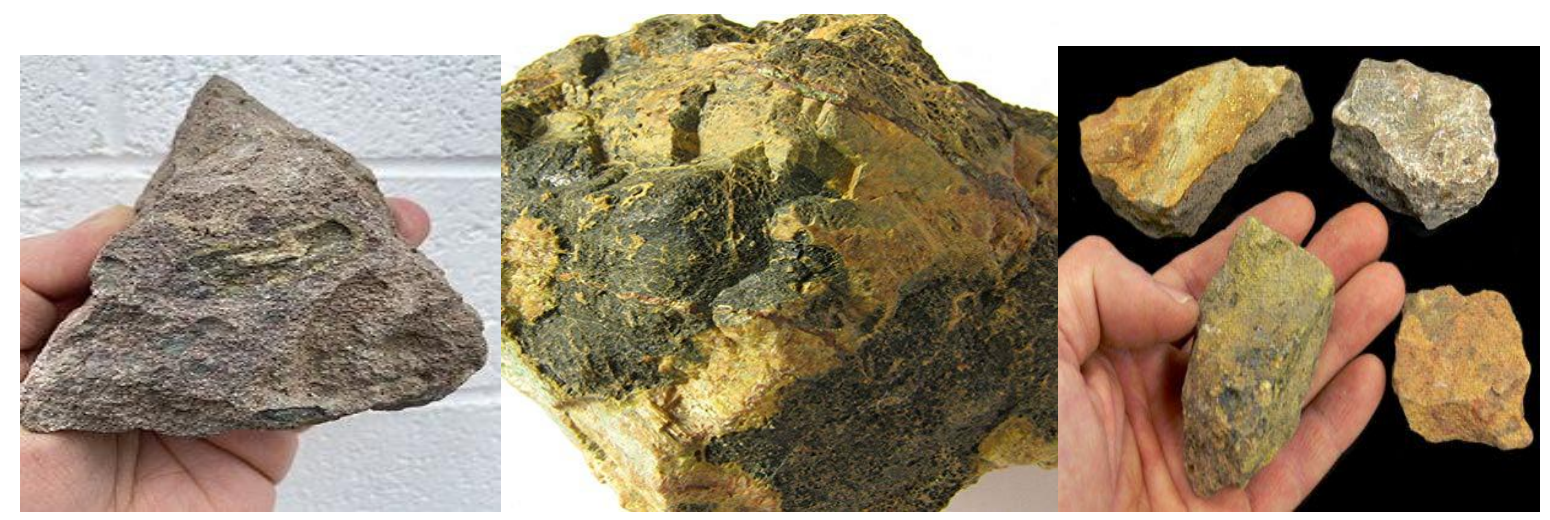

Figure 14:Uranium Ore (amazon.com)

\section{LITERATURE REVIEW}

The World Bank (2010) discussed that improved reach to power is more than enough to terminate abject suffering. Minerals from the industrial are explained to be any rock, mineral or naturally occurring substance with economic value excluding metal ores, mineral fuels and gemstones (Jeffrey, 2006). In 2009, South Africa generated about two hundred and fifty million tons of solid coal to earn the position of the $7^{\text {th }}$ highest manufacturer, globally. Renewable origin are now generally competitive with fossil fuels on an unsubsidised levelized cost of electricity (LCOE) and capital cost basis (Lazard, 2016).

\section{MATERIAL AND METHODS}

This study concentrates and talks about using minerals and mining to meet energy demands locally or globally. The method of review was utilizes in this paper.

\section{Data Mining and Methodology Data Collection}

Data and information about minerals and mineral-energy market were extracted from pages of different websites.

\section{Data Review and Analysis}

Analysed of data were done using Microsoft Excel.

\section{Data and Methodology}

The research methodology adopted comprises of information collated from online data as well as review of literatures. The author compiled these secondary data through articles of journals, books and internet mediums.

\section{Data Review and Analysis}


Table 1: Confirmed mineable coal deposits located in the top part of Africa in the year two thousand and eight (values estimated million tonnes).

\begin{tabular}{|c|c|}
\hline Country & Approximate Total Reserves \\
\hline Tanzania & 200 \\
\hline Malawi & 3 \\
\hline Zimbabwe & 502 \\
\hline Central African Republic & 2 \\
\hline Niger & 70 \\
\hline Mozambique & 212 \\
\hline South Africa & 30,156 \\
\hline Nigeria & 190 \\
\hline Botswana & 40 \\
\hline Swaziland & 144 \\
\hline Zambia & 88 \\
\hline
\end{tabular}

(Coal-Energy for Sustainable Development, 2012).

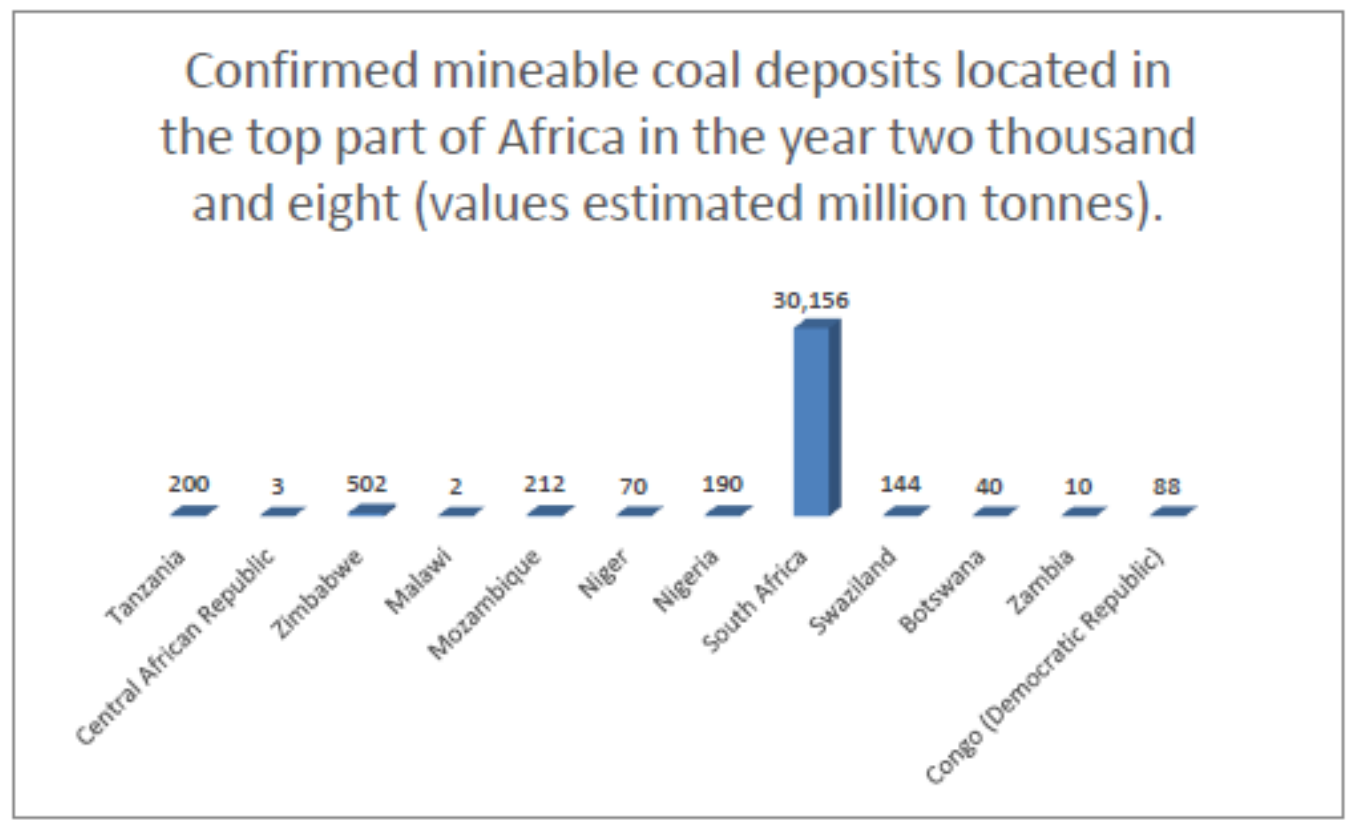

Figure 15: Confirmed mineable coal deposits located in the top part of Africa in the year two thousand and eight (values estimated million tonnes).

Table 2: Confirmed mineable coal deposits located in the Asia in the year two thousand and eight (values estimated million tonnes).

\begin{tabular}{|c|c|}
\hline Country & Total Reserves \\
\hline Mongolia & 2520 \\
\hline China & 114,500 \\
\hline Myanmar (Burma) & 2 \\
\hline Armenia & 163 \\
\hline India & 60,600 \\
\hline Georgia & 201 \\
\hline Malaysia & 4 \\
\hline Afghanistan & 66 \\
\hline Japan & 350 \\
\hline Nepal & 1 \\
\hline
\end{tabular}




\begin{tabular}{|c|c|}
\hline Kazakhstan & 33,600 \\
\hline Bangladesh & 293 \\
\hline Thailand & 1239 \\
\hline Kyrgyzstan & 812 \\
\hline Laos & 503 \\
\hline Japan & 350 \\
\hline Korea (Democratic People's Republic) & 600 \\
\hline Taiwan, China / Chinese Taipei & 1 \\
\hline Indonesia & 5529 \\
\hline Pakistan & 2070 \\
\hline Philippines & 316 \\
\hline Vietnam & 150 \\
\hline Tajikistan & 375 \\
\hline Uzbekistan & 1900 \\
\hline Korea (Republic) & 126 \\
\hline Turkey & 2343 \\
\hline
\end{tabular}

(Coal-Energy for Sustainable Development, 2012).

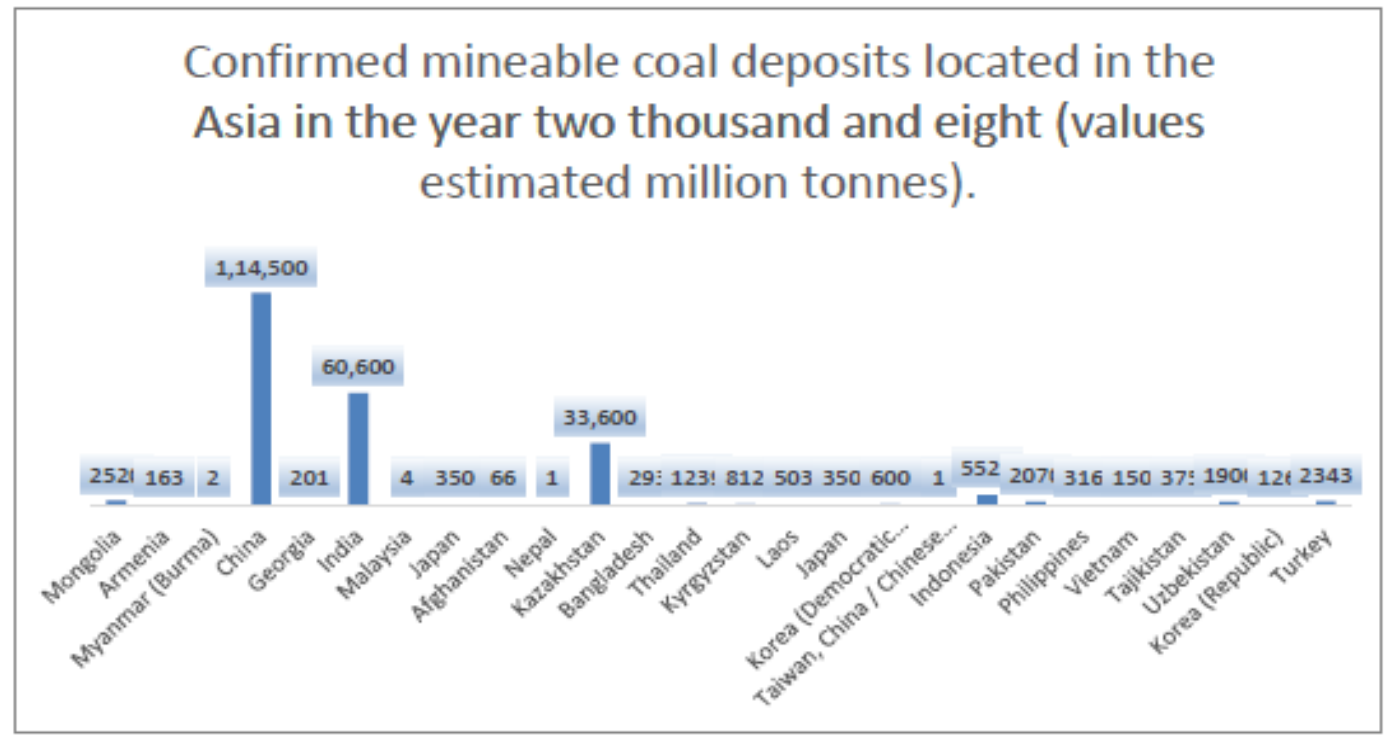

Figure 16: Confirmed mineable coal deposits located in the Asia in the year two thousand and eight (values estimated million tonnes).

Table 3: Coal used electricity generation in selected countries, globally (2008).

\begin{tabular}{|c|c|}
\hline Country & $\begin{array}{c}\text { Amount of coal used for generation } \\
\text { of electricity \% (2008) }\end{array}$ \\
\hline Australia & 77 \\
\hline Czech Rep & 60 \\
\hline Germany & 46 \\
\hline Greece & 52 \\
\hline India & 69 \\
\hline Israel & 63 \\
\hline Kazakhstan & 70 \\
\hline Morocco & 55 \\
\hline Poland & 92 \\
\hline PR China & 79 \\
\hline South Africa & 93 \\
\hline USA & 49 \\
\hline
\end{tabular}

(Coal-Energy for Sustainable Development, 2012).

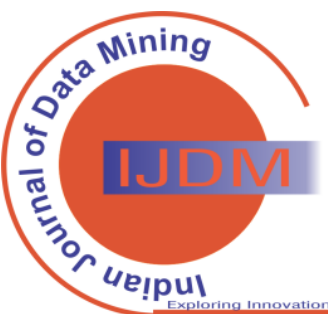




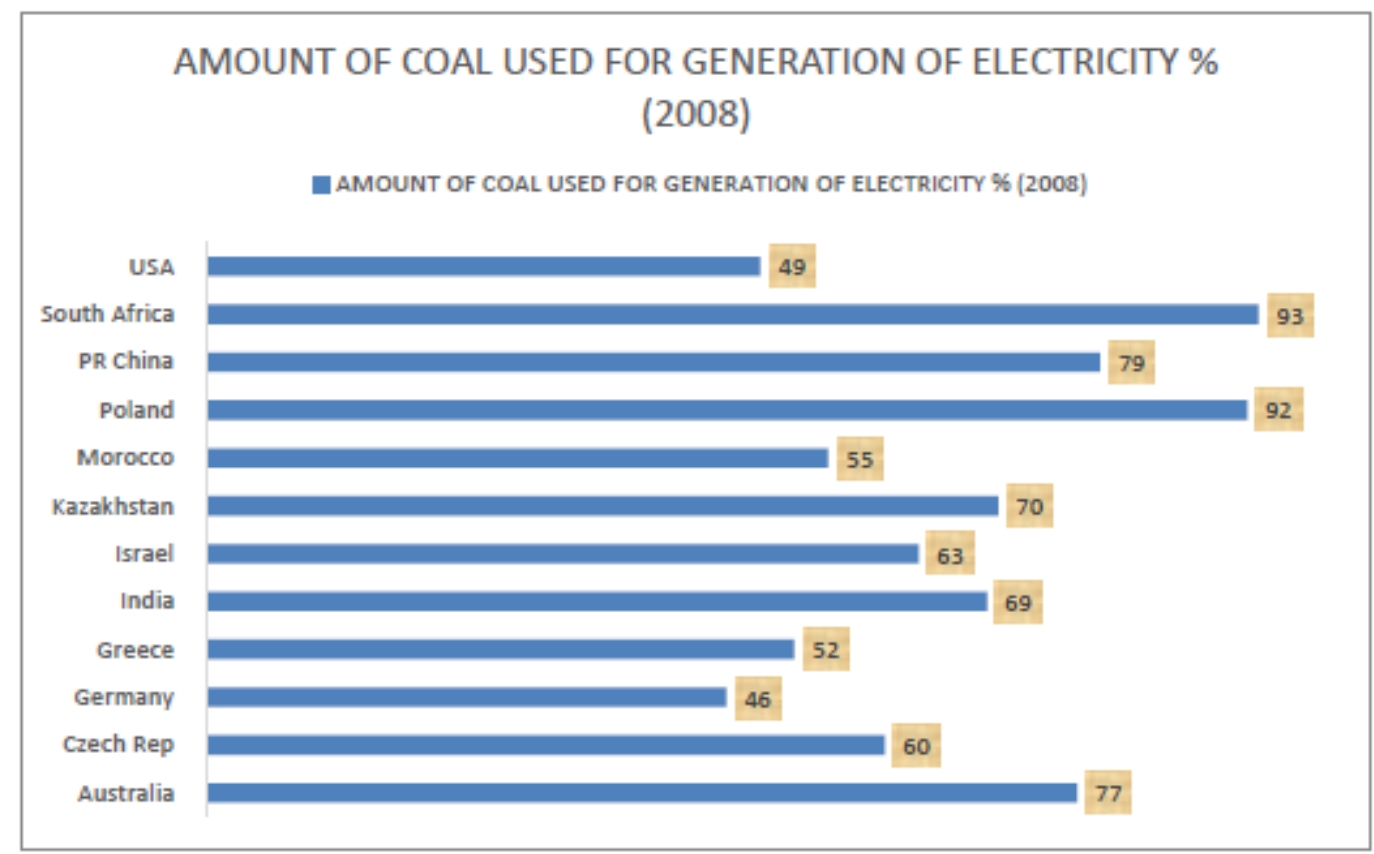

Figure 17: Amount of Coal used for generation of electricity \% (2008)

Table 4: Africa's energy statistics landscape, 2013.

\begin{tabular}{|c|c|c|c|c|}
\hline Continent & $\begin{array}{c}\text { Number of } \\
\text { People (in } \\
\text { million) }\end{array}$ & $\begin{array}{c}\text { Gross Domestic } \\
\text { Product (billion } \\
\text { USD per Year) }\end{array}$ & $\begin{array}{c}\text { Electricity } \\
\text { affordability (\% of } \\
\text { the Number of } \\
\text { People) }\end{array}$ & $\begin{array}{c}\text { Electricity } \\
\text { affordability } \\
\text { (KWH/ Capital) }\end{array}$ \\
\hline West Africa & 327 & 1310 & 47 & 188 \\
\hline North Africa & 175 & 1936 & 98 & 1574 \\
\hline Central Africa & 115 & 227 & 25 & 167 \\
\hline East Africa & 303 & 646 & 23 & 91 \\
\hline Southern Africa & 177 & 1100 & 43 & 2061 \\
\hline
\end{tabular}

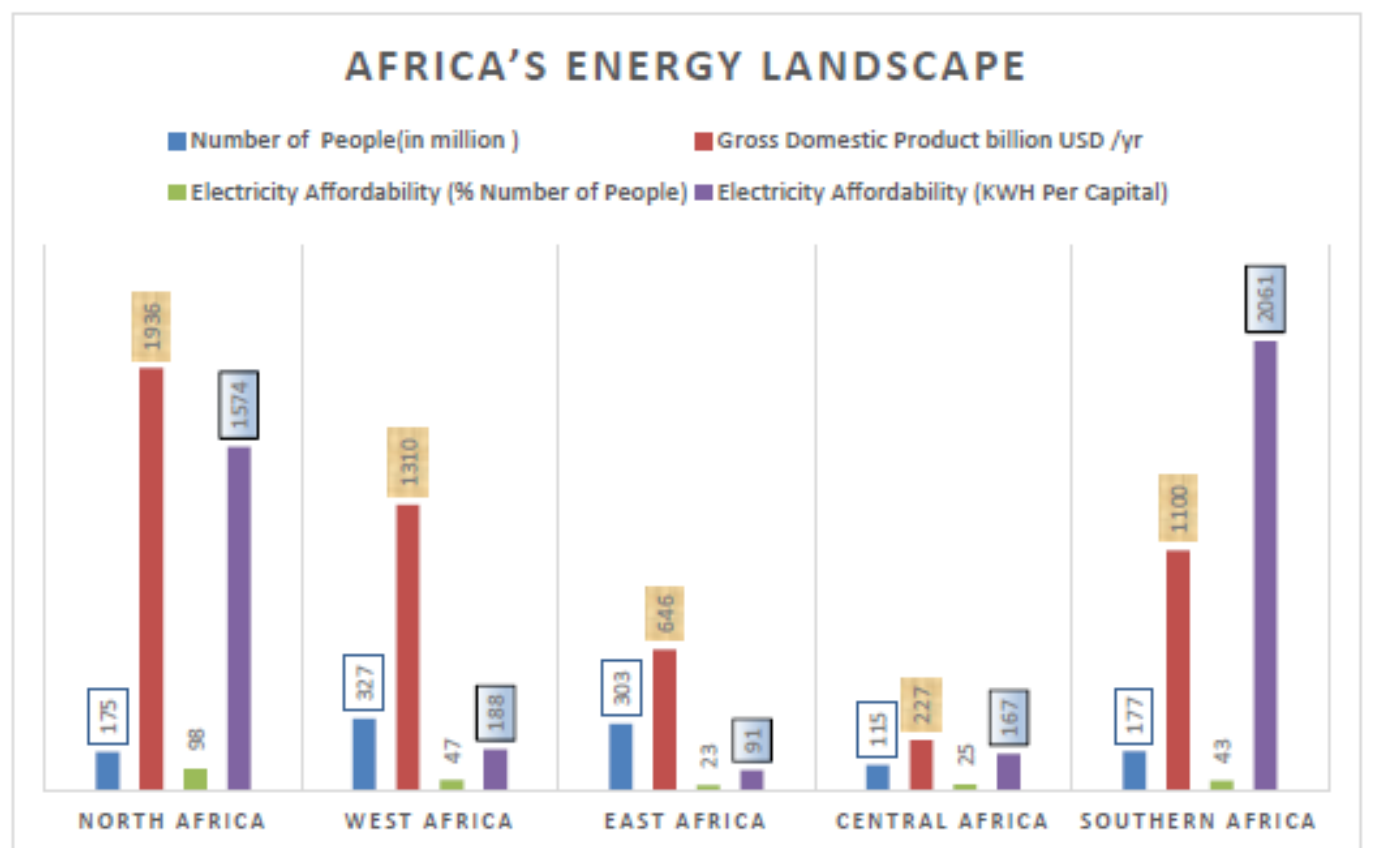

Figure 18: Producing countries in total production for selected resources and minerals (IRENA, 2015).

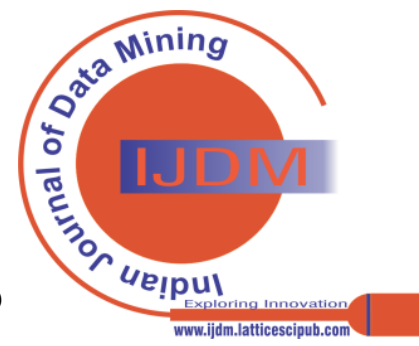


Meeting Energy Demands Through Mining

Table 5: International Energy Agency on clean energy resource progress (2019).

\begin{tabular}{|c|c|c|}
\hline Resources & Country & $\%$ of World Production \\
\hline Natural gas & $\begin{array}{l}\text { Iran } \\
\text { Russia } \\
\text { U.S.A. }\end{array}$ & $\begin{array}{c}28 \\
19.5 \\
22.5\end{array}$ \\
\hline Crude Oil & $\begin{array}{c}\text { Russia } \\
\text { Saudi Arabia } \\
\text { U.S.A. }\end{array}$ & $\begin{array}{c}30 \\
13.5 \\
18\end{array}$ \\
\hline Rare Earth & $\begin{array}{l}\text { China } \\
\text { Myanmar } \\
\text { U.S.A. }\end{array}$ & $\begin{array}{c}62.5 \\
11 \\
12.5\end{array}$ \\
\hline Platinum & $\begin{array}{l}\text { Zimbabwe } \\
\text { South Africa } \\
\text { Russia }\end{array}$ & $\begin{array}{c}9 \\
71.5 \\
12.5\end{array}$ \\
\hline Molybdenum & $\begin{array}{l}\text { Chile } \\
\text { China } \\
\text { U.S.A. }\end{array}$ & $\begin{array}{l}19 \\
45 \\
15\end{array}$ \\
\hline Nickel & $\begin{array}{l}\text { Indonesia } \\
\text { Russia } \\
\text { Philippines }\end{array}$ & $\begin{array}{l}29 \\
10 \\
15\end{array}$ \\
\hline Cobalt & $\begin{array}{c}\text { Australia } \\
\text { Russia } \\
\text { Democratic Republic of Congo }\end{array}$ & $\begin{array}{c}4 \\
4 \\
81\end{array}$ \\
\hline Lithium & $\begin{array}{l}\text { Australia } \\
\text { China } \\
\text { Chile }\end{array}$ & $\begin{array}{c}55 \\
9 \\
18\end{array}$ \\
\hline
\end{tabular}

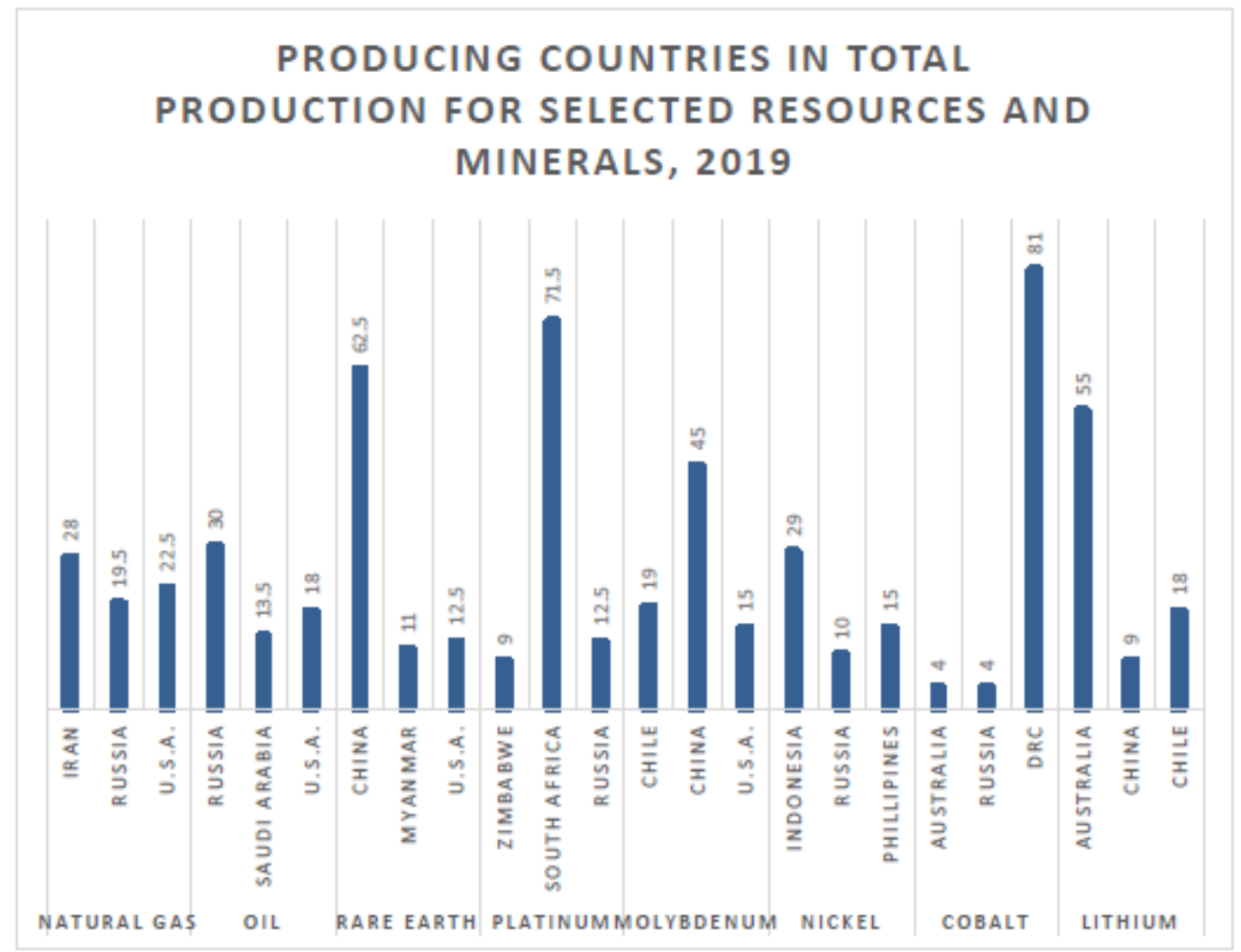

Figure 19: IEA (2020).

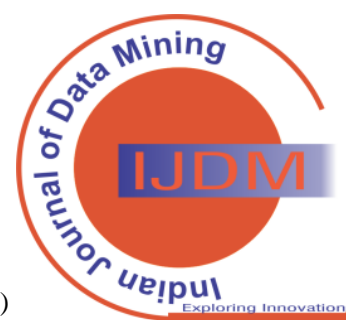


Table 6: Origin of electricity Power generation utilized in Southern Africa (NERSA, 2006).

\begin{tabular}{|c|c|}
\hline Mineral & Energy Generation in Southern Africa (\%) \\
\hline Coal & 93.2 \\
\hline Gas & 0.01 \\
\hline Oil & 0.01 \\
\hline Nuclear & 4.2 \\
\hline
\end{tabular}

POWER GENERATION IN SOUTH AFRICA
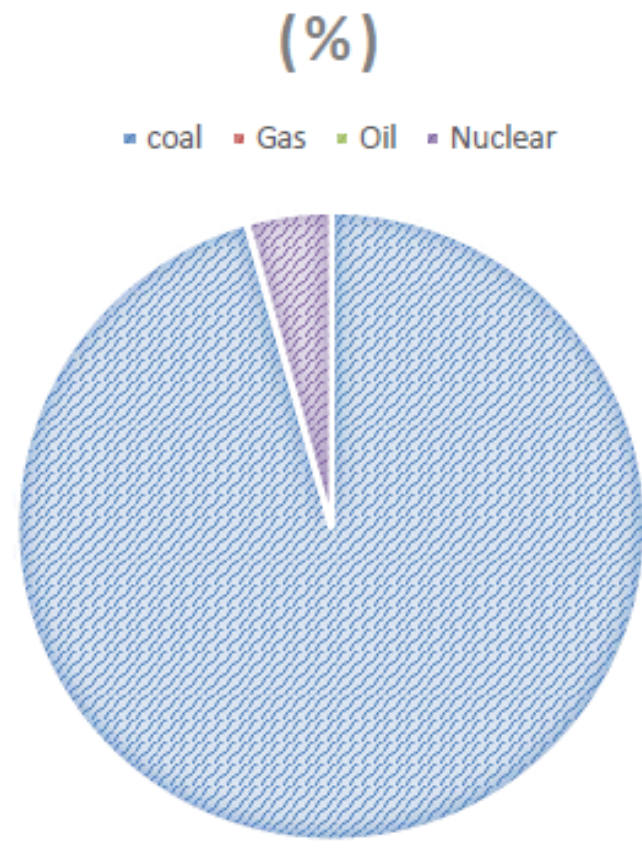

Figure 20: Power Generation in South Africa.

Table 7: Renewable energy investment in the mining industry (base case, US\$), world markets: 2013 - 2022

\begin{tabular}{|c|c|c|}
\hline \multirow{3}{*}{ Continent } & Years & $\begin{array}{c}\text { Renewable energy world market value (\$) } \\
\text { per unit }\end{array}$ \\
\hline \multirow{3}{*}{ North America } & 2013 & 38 \\
\cline { 2 - 3 } & 2018 & 262 \\
\hline \multirow{3}{*}{ Europe } & 2022 & 445 \\
\cline { 2 - 3 } & 2013 & 39 \\
\cline { 2 - 3 } & 2018 & 174 \\
\hline \multirow{3}{*}{ Asia-Pacific } & 2022 & 379 \\
\cline { 2 - 3 } & 2013 & 51 \\
\cline { 2 - 3 } & 2018 & 688 \\
\hline \multirow{3}{*}{ Latin America } & 2022 & 1343 \\
\cline { 2 - 3 } & 2013 & 37 \\
\cline { 2 - 3 } & 2018 & 532 \\
\hline \multirow{3}{*}{ Middle East and Africa } & 2022 & 1047 \\
\cline { 2 - 3 } & 2013 & 44 \\
\cline { 2 - 3 } & 2018 & 312 \\
\hline
\end{tabular}

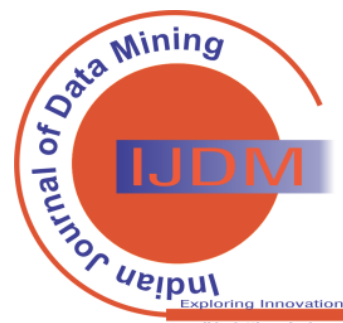




\section{Renewable Energy for the Mining Industry World Market (2013-2022 for Each continent)}

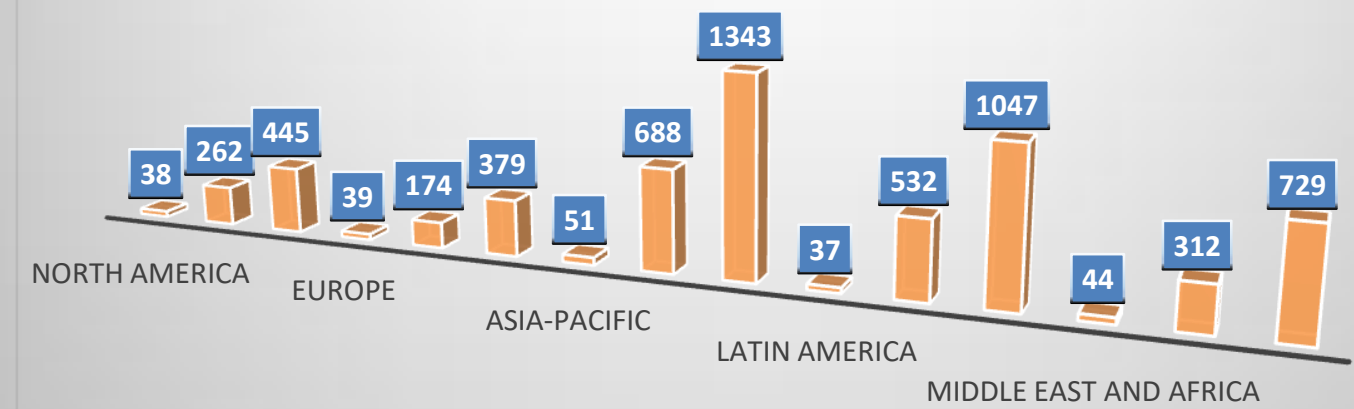

Figure 21: Renewable Energy forecast for the world market (2013-2022).

\section{RESULTS AND DISCUSSION}

In Figure 15, the confirmed mineable deposits of solid coal in the top part of Africa at the terminal of the 2008 indicates South-Africa had the highest reserves of 30,156 million tonnes followed by Zimbabwe with 502 million tonnes; but Central African Republic had the least of 3 million tonnes. In Figure 16, the confirmed mineable deposits of solid coal in parts of Asia at the terminal of 2008 shows China had the highest reserves of 114, 500 million tonnes followed by India with 60,600 million tonnes; but Nepal had the least of 1 million tonnes. In Figure 17, the amount of coal used for generation of electricity in 2008 confirms that South Africa generated the highest amount of 93\%, followed by Poland with 92\%; but Germany was the least with 46\%.In Figure 18, Africa's energy statistics landscape for the year 2013 was displayed showing Southern Africa region utilized 2,016 units of electricity in kwh per capital, even with their small relative population of 177 million people; the least utilized was East Africa with 91 units of electricity in KWH per capital, with the population of 303 million people. In Figure 19, displays the international energy agency on the progress of clean energy for the year 2019. The country that used the highest quantity of natural gas was Iran with 28\%; for crude oil was Russia with 30\%; for rare-health was China with 62.5\%; for platinum was South-Africa was $71.5 \%$; for molybdenum was China with 45\%; for nickel was Indonesia with $29 \%$; for cobalt was Democratic Republic of Congo with 81\%; and for lithium was Australia with 55\%. In Figure 20, the origin of energy utilized in the production of electricity in Southern Africa was displayed as captured by NERSA in 2006. The most utilized mineral was coal with $93.2 \%$. In Figure 21, the renewable energy investment in the mining industry's world markets from 2013 - 2022 was compiled. The highest records were set in 2022; for North America, with 445 USD per unit; for Europe, with 379 USD per unit; for Asia-Pacific, with 1343 USD per unit; for Latin America, with 1047 USD per unit; for Middle East and Africa, with 729 USD per unit. The Asia-Pacific got the overall.

\section{CONCLUSION AND RECOMMENDATION}

Meeting the demand of energy is huge, globally. Mining has its quota to contribute in the form of biomass energies (solid Coal, Gas, Petroleum, Rare-Earth Metals, Platinum, Molybdenum, Nickel, Cobalt, Lithium, Bitumen, Limestone, Oil Shale, Thorium, and Uranium). These have large potential store of energies to cater for the global economy through the market. They can be easily processed and made available for use by the populace, and its supplies last longer for energy dispensing, in heating, cooling, cooking, lighting, transportation, communication, agriculture, industry, healthcare etc. Although, innovations tend towards renewable energy demands today, mining is a strong contributor to energy supplies.

\section{REFERENCES}

1. Adedimila A.S. (2000): Bitumen, Nigeria's other Black Gold?, University of Lagos press, Lagos Nigeria.

2. Basieso M.A. et al.(2008): Jordan Oil Shale - A promising Strategy Source of Energy; Economics, Management and Polic, Page 90 129.

3. Coal (2012): Energy for Sustainable Development (World Coal Association), London, United Kingdom.

4. Degueldre C. and Joyce M.J.(2020): Evidence and uncertainty for Uranium and Thorium abundance - A review project, Nuclear Energy, 124. [CrossRef]

5. Dipali N. (2021): Carbonyl Nickel Powder Market Size, Forecast Report to 2027, ReseachGate.

6. Dipali N. (2021): Cobalt Carbonate Market Size, Forecast Report to 2027, ReseachGate.

7. Energy Kid's page (2007): - Energy Information Administration, Electric Power Annual 2006, National Energy Education Development Project, Intermediate Energy Info book, 2006.

8. Grand View Research (2019): Rare Earth Elements Market Size, Share and Trend analysis Report.

9. Hobart M.K. (2020):Rare Earth Elements and their uses.

10. IRENA (2015): Africa 2020 - Roadmap for a Renewable Energy Future, Abu Dhabi.

11. Jeffrey K (2006): Characteristics of the Industrial Minerals Sector, in Industrial Minerals and Rocks: Commodities, Markets and Markets, Kogel et al, pp.3. 
12. Kutsch J., and Kennedy J.(2013): Global Economics of Thorium Energy - Thorium Energy Alliance Portal.

13. Lazard (2016): Levelized cost of energy analysis - version 10.0

14. Lewicka E., Szlug J., Burkowicz A. and Galos K. (2020): Sources and Markets of Limestone Flour in Poland; Mineral and Energy Economy Research Institute of the Polish Academy of Sciences, ResearchGate. [CrossRef]

15. Maarten W.(2015):Natural gas providing more and cleaner energy Integrated gas and New energies, Royal Dutch shell.

16. National Energy Regulator of South Africa (NERSA) (2006), Electricity Supply Statistics 2006, pp.11-13, 18, 34.

17. Natural Gas Facts and Figure(2020):, International Gas Union: IGU News - The world LNG Report.

18. Owolabi, A. O. (1997): Evaluation of the Engineering Properties of the naturally occurring Bitumen in Ondo State, Nigeria.

19. Peggs S., et al. (2012): "Thorium Energy Futures", Proceedings of the International Particle Accelerator Conference IPAC, JACoW, pp 29-33, New Orleans, Louisiana,, USA, pp. 29-33.

20. Scrosati B., Hassoun J. and Sun Y. K., (2011): Energy and Environmental Science; 4, 3287-3295. [CrossRef]

21. Sharma A. (2020): Nickel Market Size, Analysis \& Global Forecast to 2026, ReseachGate.

22. Sinding-Larson R. and Friedrich W. W. (2012): Non-Renewable Resource Issues, Spring Dordrecht Heidelberg, London, England.

23. Traci P. (2019): Facts about Molybdenum; Live Science.

24. Transparency Market Research(2018) : Molybdenum Market Global Industry Analysis, size, share,growth and forecast 2018 2026.

25. Wang R., Mai J., Guan Y.and Liu Z.(2020): Radionuclides in the env iroment around uranium mines in Guangxi, China, 159, NJTE, Vol.14, No. 1 pp. 9 - 18, [CrossRef]

26. World Bank (2010): Addressing the Electricity Access Gap: Background Paper of World Bank Group Energy Sector Strategy, pp. $21-2$.

\section{AUTHORS PROFILE}

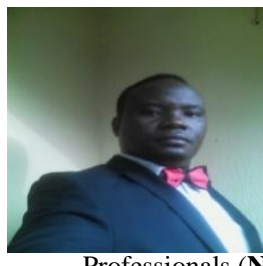

Amosu Cyril Olumuyiwa, Mining Engineer Professional background:

- Lecturer and researcher at Yaba College of Technology, Lagos, Nigeria.

- $\quad$ Associate Environmental Professionals (AEP), National registry Of Environmenta Professionals (NREP).

- $\quad$ Council for Regulation of Engineering In Nigeria (COREN).

Education:

- $\quad$ Master of Engineering (M. Eng.) in Mining Engineering from Federal University of Technology Akure, Nigeria (2019 - Date).

- Masters (M. Sc.) in Petroleum Engineering and Project Development (2004 - 2005).

- $\quad$ Bachelors of Engineering (B. Eng.) in Mining Engineering from Federal University of Technology Akure, Nigeria (1995 - 2001).

\section{Previous publishing experience}

About ten (10) journals published already with different publishers which can be found on Google Scholar, ResearchGate, Publon and Orcid. These journals captures Mining and Petroleum.

\section{Personal details:}

Married with three (3) children; lives in Lagos state, Nigeria; Personal interest is writing and research.

\section{Contact information:}

Personal E-mail: muyixx1zillion@gmail.com

Official E-mail: Cyril.amosu@yabatech.edu.ng

Phone Number: +2348036302750; +2348021910353

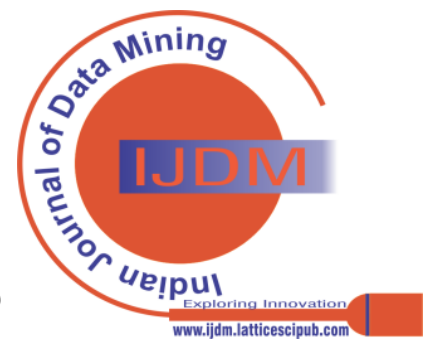

